\title{
EDUKASI KERAJINAN DAUN KELAPA UNTUK PENGEMBANGAN INDUSTRI KREATIF DESA DURIAN LOMBOK TENGAH
}

\author{
Alda Fadila ${ }^{1}$, Jazera Alfani ${ }^{2}$, Farhan Zulfikar ${ }^{3}$, Yossica Miranda ${ }^{4}$, \\ Denies Mulkan Azima ${ }^{5}$, Aurelius R.L. Teluma ${ }^{6 *}$ \\ 1,2,3,4,5,6Program Studi IImu Komunikasi Universitas Mataram \\ *email: aureliusteluma@unram.ac.id
}

\begin{abstract}
ABSTRAK. Mitra kegiatan PKM-M EDKERDAPA adalah penduduk desa Durian, kecamatan Janapria, kabupaten Lombok Tengah, Provinsi Nusa Tenggara Barat (NTB). Desa Durian merupakan desa dengan luas wilayah sekitar 476 ha yang memiliki pebun kelapa yang luas. Kelompok mengidentifikasi beberapa permasalahan warga yakni: 1) Kurangnya pemahaman terhadap industri kreatif dan kerajinan tangan baik pada tahap produksi maupun pemasaran; 2) Kurangnya kemauan dan semangat masyarakat desa Durian untuk membuat suatu inovasi baru, kebanyakan wanita yang sudah menikah di desa Durian tidak bekerja dan hanya menjadi ibu rumah tangga; 3) Minimnya pengetahuan tentang pemasaran online. Maka Langkah pemecahan yang kami lakukan antara lain: 1) Membentuk kelompok usaha yang dapat meningkatkan kesejahteraan masyarakat desa Durian dengan kelompok warga yang kami sasar adalah ibu-ibu Desa Durian yang memiliki banyak waktu luang; 2) Membagi tugas ibu-ibu desa Durian yang mengikuti pelatihan tersebut, jadi sebagian ibu-ibu fokus untuk pembuatan kerajinan dan sebagian lagi diberi tugas tambahan untuk belajar lebih banyak lagi terkait marketing online; 3) Menjalin kerja sama dengan pihak-pihak yang berpengalaman dalam pengembangan ekonomi kreatif berbasis kerajinan tangan agar membantu dalam proses pelatihan maupun dalam pengembangan usaha nanti. Target luaran kegiatan antara lain: 1) Terbentuknya Kelompok Pengrajin daun kelapa di desa Durian yang tetap dan kontinu untuk dapat melakukan kegiatan-kegiatan lainnya yang berkaitan dengan kerajinan tangan; 2) Laporan Kemajuan dan Laporan Akhir; 3) Artikel ilmiah yang berisi tentang latar belakang, landasan pemikiran dan gambaran umum serta informasi tentang pengembangan kerajinan tangan di desa Durian Lombok Tengah yang telah dilaksanakan oleh kelompok EDKERDAPA. Hasil evaluasi menunjukkan bahwa proses dan tahapan kegiatan telah dilaksanakan sesuai yang telah direncanakan.
\end{abstract}

Kata Kunci: Edukasi Kerajinan Kelapa, Desa Durian, Industri Kreatif

ABSTRACT. The partner of the EDKERDAPA group activity is the residents of Durian village, Janapria sub-district, Central Lombok district, West Nusa Tenggara Province (NTB). Durian Village is a village with an area of around 476 ha which has extensive coconut plantations. The group identified several community problems, namely: 1) Lack of understanding of creative industries and handicrafts both in the production and marketing stages; 2) The lack of willingness and enthusiasm of Durian villagers to make a new innovation, most married women in Durian village do not work and only become housewives; 3) The lack of knowledge about online marketing. Then the solution steps we have taken include: 1) Forming a business group that can improve the welfare of the Durian village community with the target groups we are targeting is Durian Village mothers who have a lot of free time; 2) Sharing the tasks of Durian village mothers who took part in the training, so some mothers focused on making crafts and some were given additional 
assignments to learn more about online marketing; 3) Establish cooperation with parties who are experienced in developing a creative economy based on handicrafts to assist in the training process and in developing the business later. Output targets for the activity include: 1) Establishment of a permanent and continuous coconut leaf craftsman group in Durian village to be able to carry out other activities related to handicrafts; 2) Progress and Final Report; 3) Scientific articles which contain background, rationale and general description as well as information about handicraft development in Durian village, Central Lombok, which has been carried out by the EDKERDAPA group. Evaluation results indicate that the process and stages of activities have been carried out as planned.

Keyword: coconut craft training, Durian village, creative industry

\section{PENDAHULUAN}

Desa Durian, kecamatan Janapria, kabupaten Lombok Tengah, Provinsi Nusa Tenggara Barat (NTB) merupakan desa dengan luas wilayah sekitar 476 ha. Waktu tempuh dari kota Mataram menuju desa Durian sekitar 1,5 jam dengan kendaraan bermotor. Desa Durian merupakan sebuah desa yang dikelilingi oleh lahan pertanian dengan tingkat kesuburan tanah yang tinggi. Berdasarkan data yang didapat dari profil desa Durian, jumlah warga desa Durian adalah sebanyak 3.134 orang. Jumlah penduduk laki-laki yaitu 1.443 orang sedangkan jumlah perempuan di desa adalah 1.691 orang dengan jumlah kepala keluarga $974 \mathrm{KK}$. Kepadatan penduduk yang ada di desa Durian sebesar 657 orang per km. Penduduk yang tergolong dalam usia produktif (15-64 tahun) sebanyak 1.567 jiwa atau $56,14 \%$ dari jumlah seluruh penduduk. Orang tua yang ada di desa Durian mayoritas hanya menempuh pendidikan dasar saja namun saat ini sudah banyak anak-anak desa Durian yang disekolahkan hingga tingkat menengah atas dikarenakan kesadaran akan pendidikan mulai tumbuh serta tersedianya sarana pendidikan di desa Durian.

Kondisi ekonomi masyarakat desa Durian terbilang masih rendah, mayoritas penduduknya berprofesi sebagai petani dan peternak, sumber penghasilan utama masyarakat desa Durian berasal dari sektor pertanian dan peternakan. Masyarakat hanya mengandalkan pertanian dan peternakan sebagai satu-satunya sumber penghasilan, Hal ini kemudian mempengaruhi kondisi perekonomian masyarakat dikarenakan varietas pertanian mereka merupakan jenis tanaman musiman sehingga masyarakat hanya mendapatkan penghasilan pada saat musim panen saja. Untuk itu program EDKERDAPA bertujuan untuk membantu perekonomian masyarakat di saat masyarakat tidak sedang dalam musim panen. Tujuannya adalah agar masyarakat menjadi mandiri dan tidak terlalu bergantung dengan hasil pertanian dan peternakan.

Desa Durian memiliki potensi sumber daya alam yang cukup melimpah, tanah yang subur serta akses jalan yang sudah bagus harusnya mampu dimanfaatkan dengan baik. Listrik, jaringan telepon dan internet pun sudah sangat baik, namun hanya sebagian masyarakat saja yang dapat menggunakannya karena sebagiannya masih belum mampu. Masyarakat desa Durian masih memegang erat kebudayaan yang ada, masyarakat masih sering melakukan kegiatan gotong royong, dimana segala sesuatunya masih berdasarkan nilai-nilai kekeluargaan, namun bukan berarti masyarakatnya menjadi tertutup terhadap hal baru yang masuk ke desa, masyarakat desa Durian cukup terbuka dan sangat antusias terhadap hal-hal baru yang dirasa baik untuk masyarakat setempat. Masyarakat sangat ramah dan mendukung program-program yang masuk ke desa. 


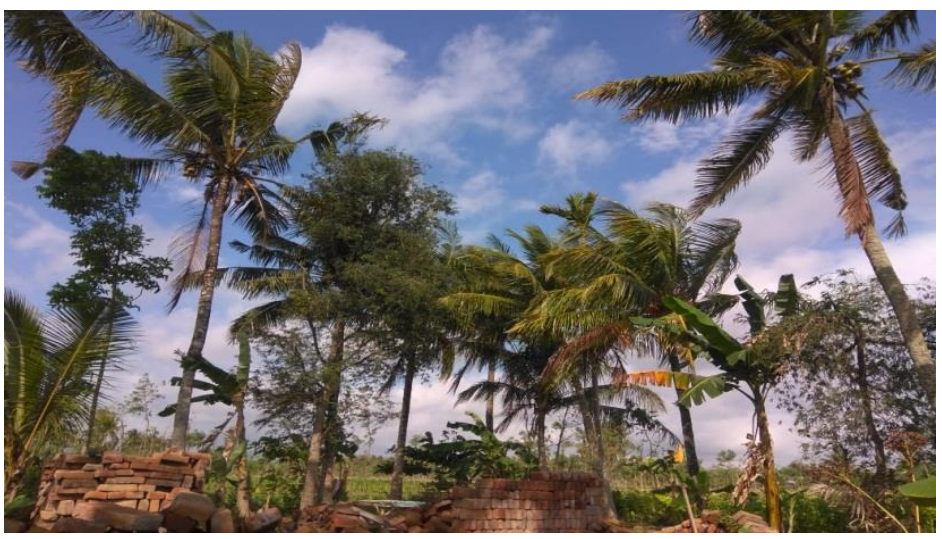

Gambar 1. Lahan pohon kelapa di Desa Durian

Lahan yang ada di desa Durian sebagian besar digunakan untuk bertani. Masyarakat lebih cenderung menanam padi lokal karena tahan serangan organisme pengganggu tanaman (OPT), dapat disimpan lama dan benihnya dapat ditanam kembali. Selain padi, Di Desa Durian juga terdapat banyak pohon kelapa yang sebagian besar masyarakat hanya memanfaatkan buahnya untuk kebutuhan sehari-hari. Selebihnya masyarakat membiarkan pohon kelapa tersebut tanpa adanya pengolahan lanjutan. Sudah ada beberapa warga desa Durian yang mulai mencoba untuk memanfaatkan sumber daya alam yang ada di desa tersebut yaitu daun kelapa, dengan cara mengolahnya menjadi barang-barang kerajinan, namun kegiatan tersebut masih sangat minim dan hanya dilakukan oleh beberapa orang saja, padahal jika masyarakat mau memanfaatkannya dengan baik, hal itu bisa saja menjadi sumber mata pencaharian baru bagi masyarakat desa Durian.

Kita bisa melihat potensi tersebut dari hasil kerajinan yang mereka buat seperti sapu lidi dan tikar. Dalam hal ini masyarakat sudah memiliki potensi yang cukup memungkinkan untuk selangkah lebih maju. Namun potensi itu akan sia-sia jika tidak adanya tindakan dari pemerintah untuk mengembangkan potensi tersebut. Untuk itu, pemberdayaan serta edukasi kepada masyarakat sangat diperlukan agar masyarakat lebih peduli terhadap potensi alam yang ada disekitar mereka. Sehingga pohon kelapa yang melimpah di desa Durian tidak lagi dianggap sebagai sesuatu yang tidak memiliki nilai jual, setelah dimanfaatkan dengan baik diharapkan kerajinan dari daun kelapa ini dapat menjadi salah satu sumber penghasilan masyarakat setempat

\section{ANALISIS PERMASALAHAN}

Desa Durian merupakan desa dengan sumber daya alam yang melimpah, kondisi desa yang masih sangat asri dan penuh dengan pepohonan merupakan hal baik yang patut untuk disyukuri, karena hal itulah kami merasa bahwa perlu adanya pengembangan dan pemberdayaan masyarakat sebab dengan sumber daya alam yang ada, bukan tidak mungkin masyarakat dapat meningkatkan kesejahteraannya melalui pemanfaatan sumber daya alam di desanya. Berdasarkan pengamatan tersebut serta diskusi awal bersama beberapa warga dan pengurus desa Durian dalam survei pertama maupun kedua (lihat foto lampiran 3), kami mengidentifikasi beberapa permasalah sebagai berikut:

1) Kurangnya pemahaman terhadap industri kreatif dan kerajinan tangan baik pada tahap produksi maupun pemasaran.

2) Kurangnya kemauan dan semangat masyarakat desa Durian untuk membuat suatu inovasi baru, $70 \%$ wanita yang sudah menikah di desa Durian tidak bekerja dan hanya 
menjadi ibu rumah tangga. Hal ini membuat ibu-ibu desa Durian memiliki banyak waktu luang yang belum dimanfaatkan dengan baik.

3) Minimnya pengetahuan tentang pemasaran online bahkan sebagian besar ibu-ibu yang kelak mengikuti pelatihan, tidak menggunakan handphone android yang dapat digunakan sebagai media untuk pemasaran online kerajinan tersebut.

Kami melihat ini hal sebagai suatu hambatan tetapi juga peluang. Untuk itu, kami menyusun rencana solutif untuk menyelesaikan beberapa masalah yang dihadapi oleh masyarakat desa Durian tersebut, yang memiliki sumber daya alam yang melimpah khususnya pohon kelapa. Langkah pemecahan yang kami lakukan untuk mengatasi masalah tersebut antara lain:

1) Masyarakat yang tidak mempunyai pekerjaan dapat belajar membuat kerajinan dengan membentuk kelompok usaha yang dapat meningkatkan kesejahteraan masyarakat desa Durian. Kelompok warga yang kami sasar adalah ibu-ibu Desa Durian yang memiliki banyak waktu luang.

2) Membagi tugas ibu-ibu desa Durian yang mengikuti pelatihan tersebut, jadi sebagian ibu-ibu fokus untuk pembuatan kerajinan dan sebagian lagi diberi tugas tambahan untuk belajar lebih banyak lagi terkait marketing online.

3) Menjalin kerja sama dengan pihak-pihak yang berpengalaman dalam pengembangan ekonomi kreatif berbasis kerajinan tangan agar membantu dalam proses pelatihan maupun dalam pengembangan usaha nanti.

\section{METODE PELAKSANAAN}

Pelaksanaan kegiatan PKM EDKERDAPA dilakukan dengan metode pelatihan langsung atau learning by doing. Secara detil diuraikan sebagai berikut:

\section{1) Sosialisasi Program}

Tahap sosialisasi ini diawali dengan mendata jumlah penduduk yang ada di Desa Durian melalui kantor Desa Durian. Sebelum melakukan kegiatan sosialisasi ini, kami melakukan survey dengan pihak desa dan masyarakat setempat sebanyak 3 kali. Kami melakukan sosialisasi ini pada hari Rabu, 15 Juni 2019 dengan jumlah peserta yang hadir sebanyak 20 orang. Kemudian, peserta kami kenalkan dan dijelaskan tentang program EDKERDAPA. Pada saat kegiatan sosialisasi masyarakat terlihat cukup antusias terbukti dengan banyaknya pertanyaan dan banyaknya masyarakat yang mengajak untuk berdiskusi. Kegiatan sosialisasi ini ditutup dengan sesi tanya jawab dan diskusi serta membahas mengenai jadwal pertemuan selanjutnya.

\section{2) Penyusunan Rencana Kegiatan dan Materi Pelatihan}

Agar kegiatan lebih terencana maka kelompok menyusun Rencana Pelaksanaan Kegiatan untuk menjadi panduan pelaksanaan. Rencana pelaksanaan kegiatan tersebut disusun oleh kelompok dan diketahui oleh Dosen Pembimbing agar lebih teratur dan sesuai tujuan kegiatan.

\section{3) Persiapan Tempat, Alat dan Sarana}

Setelah menjadwalkan kegiatan bersama masyarakat desa Durian, kami mulai mempersiapkan alat dan bahan yang butuhkan untuk melaksanakan kegiatan pelatihan pembuatan kerajianan dari kelapa. Untuk bahan berupa daun kelapa, kami bekerja sama dengan masyarakat desa Durian untuk menyiapkan daun kelapa tersebut, karena memang di desa Durian, banyak sekali pohon kelapa yang tumbuh di sekitar rumah dan kebun-kebun di desa Durian, jadi daun kelapa tersebut dibiarkan mengering sendiri selama seminggu, tidak perlu dijemur di bawah sinar matahari, karena 
di khawatirkan daun tersebut terlalu kering. Karena bahan utama seperti daun kelapa sudah disediakan oleh warga, maka alat-alat seperti Gunting, Lem kayu, Karton, Spidol, Benang nilon, Cat/pengkilat, Pengait, Kuas, Kain, Penggaris dll, kami sediakan sebelum melaksanakan kegiatan pelatihan kerajinan tersebut.

\section{4) Pelatihan pembuatan kerajinan tangan olahan daun kelapa.}

Pelatihan pembuatan kerajinan tangan dari daun kelapa ini kami laksanakan sebanyak 3 kali, 2 kali pertemuan sebelum hari raya dan 1 kali pertemuan setelah hari raya. Semua kegiatan tersebut terdokumentasi dengan baik dalam bentuk foto dan video. Dengan 3 kali pertemuan pelatihan kerajinan tersebut, masyarakat desa Durian sudah mampu untuk mengembangakan berbagai macam kerajinan yang sudah diajarkan. Pertemuan pertama, masyarakat dikenalkan dengan bahan-bahan yang akan digunakan dalam pembuatan kerajinan, selanjutnya di pertemuan kedua masyarakat desa diajarkan untuk membuat suatu produk yaitu kotak tisu dan toples. Masyarakat mampu menyelasaikan produk kotak tisu dan toples itu dalam suatu kali pertemuan. Pertemuan ketiga, masyarakat diajarkan membuat tas berbahan dasar batok kelapa. Jadi dalam 3 kali pelatihan, kami sudah mengajarkan pembuatan 3 macam produk dan setelah itu, kami memberikan ruang untuk masyarakat dapat berkreasi dengan tetap kami dampingi.
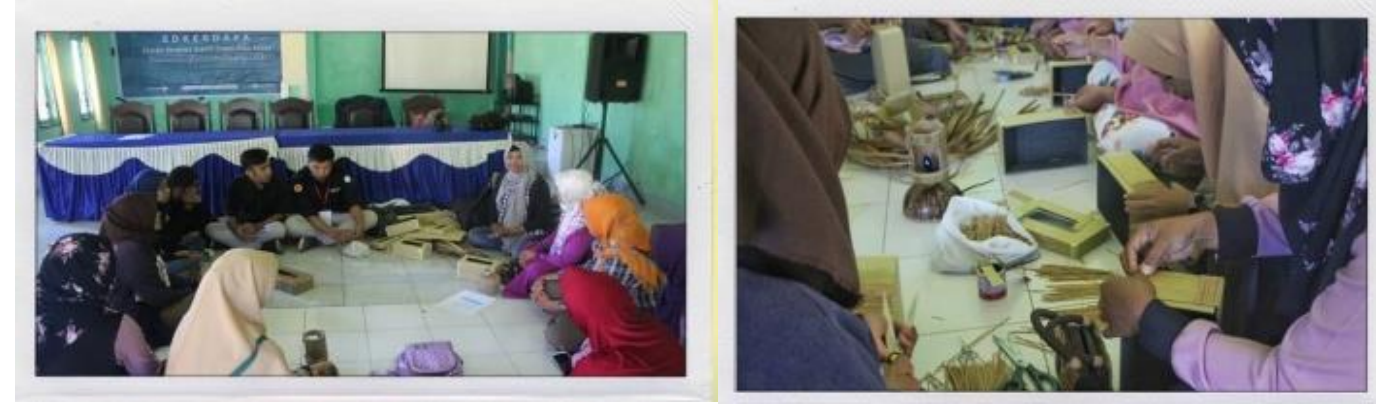

Gambar 2. Pelaksanaan pelatihan kerajinan daun kelapa

\section{5) Pelatihan pemasaran online}

Untuk kegiatan pelatihan pemasaran online, kami melakukan pertemuan sebanyak 1 kali dan membahas mengenai strategi marketing online. Pertemuan dengan agenda pelatihan strategi marketing online bertujuan untuk membina masyarakat dalam hal promosi dan pemasaran produk dengan memanfaatkan media, pelatihan ini dilakukan agar dapat memberikan ilmu tentang strategi pemasaran yang bisa memperluas pangsa pasar produk masyarakat desa Durian, salah satu strategi pemasaran yang efektif untuk digunakan yakni dengan menggunakan teknologi atau sering disebut bisnis online. Dengan memanfaatkan internet, masyarakat dea Durian bisa mempromosikan serta memasarkan produk kepada masyarakat luas. Melalui website, facebook, instagram, twitter dan lainnya. Produk yang dihasilkan dapat dikenal orang banyak, dan membuat konsumen tertarik untuk memesan. Usaha tidak bisa berjalan dengan baik apabila pemasarannya tidak baik. Melalui pemasaran, produk dapat dikenal konsumen, dan dapat meningkatkan omset penjualan serta memperoleh keuntungan. Sejauh ini kami sudah membuatkan 2 tempat penjualan produk, yaitu facebook dan instagram. 


\section{HASIL DAN PEMBAHASAN}

Proses dan tahapan kegiatan telah dilaksanakan sesuai yang telah direncanakan. Begitupula, jumlah luaran juga dapat tercapai sesuai dengan tahapan masing-masing.

Target luaran pertama kegiatan ini adalah Pembentukan Kelompok Pengrajin daun kelapa di desa Durian. Sejauh ini sudah ada kelompok yang terbentuk dari pelatihan yang kami lakukan, kelompok tersebut terdiri dari ibu-ibu PKK desa Durian dan beberapa warga yang mengikuti pelatihan. Kelompok tersebut terdiri dari 10 orang yang dilihat cukup mampu dan tekun mengikuti pelatihan. Rencananya kelompok tersebut akan mulai membuat desain-desain baru pengembangan dari kerajinan yang kami ajarkan. Secara kuantitatif, berdasarkan lembar observasi yang disiapkan oleh kelompok diperoleh gambaran bahwa terjadi peningkatan ketrampilan anggota kelompok pengrajin dalam pembuatan kerajinan maupun pemasaran online. Peningkatan tersebut tergambar dalam diagram berikut:

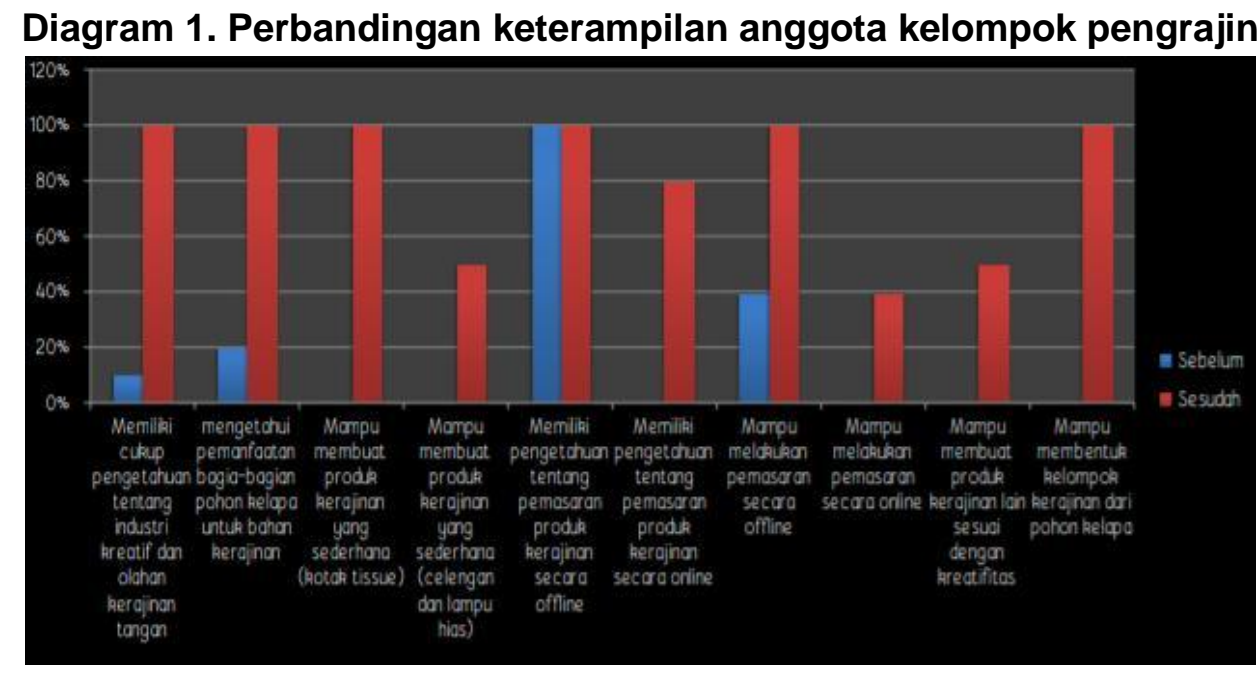

Target luaran berikutnya adalah tersusunnya Laporan Kemajuan, Laporan Akhir Kegiatan dan Artikel IImiah. Laporan kemajuan kegiatan telah selesai disusun dan dikirimkan ke Belmawa Kemristekdikti pada bulan Juni 2019. Sedangkan laporan akhir telah dibuatkan rancangannya yang mencakup sekitar $80 \%$ dari isi keseluruhan. Kami menyusun laporan tersebut bersama-sama dengan menyesuaikan jadwal masing-masing terlebih dahulu. Sementara itu, Artikel ilmiah juga telah disusun sesuai standar penulisan artikel ilmiah yang lengkap.

Kedua target luaran yang telah dicapai di atas akhirnya bertujuan untuk meningkatkan industri kreatif di pededasaan Lombok, khususnya di desa Durian. Bagaimana pun, salah satu sektor yang digeluti usaha kecil menengah yang sangat memungkinkan untuk dikembangkan adalah industri kreatif. Industri kreatif merupakan industri yang berasal dari pemanfaatan kreativitas, keterampilan serta bakat individu untuk menciptakan kesejahteraan serta lapangan pekerjaan melalui penciptaan dan pemanfaatan daya kreasi dan daya cipta individu tersebut (Departemen Perdagangan Republik Indonesia, 2007). Sumber daya manusia kreatif dan kekayaan warisan budaya adalah merupakan modal yang kuat bagi bangsa Indonesia untuk bersaing di industri kreatif. Sektor industri ini lebih mengintensifkan penggunaan informasi pasar, kreativitas dan didukung sumber daya manusia yang kreatif. Dengan bekal ini UKM diharapkan bisa bersaing dengan industri besar yang seringkali lebih efisien dan berbiaya produksi lebih murah (Raldianingrat, 2014). Hasil penelitian Muafi et al. (2012), menjelaskan bahwa UKM memiliki kemampuan yang lemah dari aspek SDM, teknologi informasi dan inovasi. Padahal disatu sisi, UKM memiliki kontribusi kuat terhadap 
perekonomian suatu negara. Di Indonesia, UKM dikenal sebagai salah satu penopang ekonomi saat krisis tahun 1997 (Sarosa, 2007 dalam Raldianingrat, 2014).

Satu kendala yang menantang kami di lapangan adalah kurangnya pengetahuan masyarakat tentang penggunaan teknologi seperti smartphone dll. Salah satu kesulitan yang kami alami adalah ketika memberikan pelatihan mengenai pemasaran online. Sebagian besar masyarakat desa Durian yang mengikuti pelatihan tidak terbiasa menggunakan smartphone, yang dimana untuk dapat mengakses internet kita membutuhkan smartphone. Tantangan tersendiri bagi kami untuk menjelaskan tiap fitur dalam smartphone dan bagaimana menggunakannya sebagai media pemasaran produk yang mereka buat. Akhirnya langkah yang kami lakukan untuk mengatasi hambatan ini adalah, kami akan tetap mendampingi masyarakat desa Durian dalam hal pemasaran produk secara online, selain itu kami menunjuk beberapa orang dari masyarakat sebagai kordinator di bagian pemasaran yang memang sudah memiliki pengetahuan tentang penggunaan internet. Kami mengupayakan agar dengan menunjuk beberapa orang yang terlihat lebih mampu tersebut, maka mereka dapat melatih yang lainnya ketika di luar jam pelatihan.

\section{KESIMPULAN}

Kegiatan pengabdian berupa pelatihan keterampilan kerajinan kelapa di desa Durian merupakan salah satu solusi yang dapat membantu warga setempat mengembangkan ekonominya melalui pemanfaatkan potensi alam lokal. Metode pelatihan dengan praktik bersama atau learning by doing merupakan langkah yang tepat agar mempercepat penguasaan keterampilan pembuatan kerajinan. Sekalipun demikian, selain dalam hal produksi, pelatihan industri kreatif semacam ini perlu dilengkapi dengan pelatihan pemasaran khususnya pemasaran berbiaya murah yakni memanfaatkan teknologi internet atau online.

\section{UCAPAN TERIMA KASIH}

Kegiatan PKM Edkerdapa terlaksana berkat pemberian hibah dana oleh Dirjen Belmawa Kemristekdikti tahun 2018. Untuk itu terima kasih kami haturkan untuk Kemristekdikti, Universitas Mataram, dan Dosen Pembimbing PKM Edkerdapa..

\section{REFERENSI}

Muafi, H. Gusaptono, N. Charibaldi, dan I. Effendi,. 2012. "The Information Technology (IT) Adoption Process and EReadiness to Use within Yogyakarta Indonesia Small Medium Enterprises (SME)." International Journal of Information and Communication Technology Research, February 2(1): 29-37

Welis Raldianingrat, W dan Wuryanti. 2014. "Upaya Peningkatan Kinerja Industri Kreatif Kerajinan Melalui People Equity dan Strategi Inovasi di Kabupaten Konawe." EKOBIS Vol.15, No.2, Juli 2014 : 102 - 112. 